\title{
The Physical Effects of the Fitness Exercises
}

\author{
Nigar Yaman \\ Physical Education and Sports Department, Bartin University, Turkey
}

Copyright $(2016$ by authors, all rights reserved. Authors agree that this article remains permanently open access under the terms of the Creative Commons Attribution License 4.0 international License.

\begin{abstract}
In this study, the physical changes in 36 male participants were examined over 12 weeks, during which they have carried out fitness exercises to see whether there is a physical change in the individuals who prefer the type of fitness exercises that include walking, running, pedaling and weight exercises as a form of sportive activity. An exercise protocol including warm up, cool down, walking, running, pedaling and weight exercises in an average duration of 90 minutes was applied to the participants for 4 days a week during the period of the aforementioned 12 weeks. Including pre-exercises, the body weight, girth measurement, body fat percentages and body mass indexes were measured and noted in the fourth, eighth and twelfth weeks. The data was analyzed through one-way ANOVA tests for mean, standard deviation and correlated samplings. No significant difference was found in the body mass indexes of the participants. Biceps, chest, shoulder and thigh measurements showed a significant increase in the end of the 12 week period. The body fat percentages showed decreased results in all of the measurements when compared to the measurements of pre-exercise. As a result, the fitness exercises that were performed throughout the 12-week period, showed a positive benefit in the girth measurements and body fat percentages starting from the fourth week. Body mass indexes did not reflect any differences in relation with the increased muscle volume.
\end{abstract}

Keywords Exercise, Fitness, Body Mass Index, Physical Fitness

\section{Introduction}

In this day and time, lack of movement is described as an illness and shown as the cause for many terminal illnesses. Cardiovascular illness can be shown as the most important of these illnesses. With the development of the technology, the technological devices being an irreplaceable part of people's daily lives, is the root cause of immobility. Sedentary life style causes many serious health problems. Illnesses such as muscular weakness, postural disorder, diabetics and many more including obesity and cardiovascular illnesses that are named as the illnesses of the contemporary era, are more often seen in immobile and sedentary individuals. Lack of sport consciousness and accepting sport as a lifestyle are the root causes of these illnesses [1].

In societies where sport is accepted as a lifestyle, interest in sport and various sport activities has grown. The time spared for the individual's self and the value they put on their health are at the optimal levels [2],[3].

Herguner (2015) "Sports is the performance enhancing, socializing and instructive psycho-motor activities based on mental and physical competition, assessed by the units of measurement for weight, length, time and the score, requiring planned work and obedience to the rules, performed with or without equipment, individually or as a team, by using different areas and with various purposes" [4].

Physical fitness covers cardiovascular durability, muscle strength, muscular durability, body composition and parts of the body. It is a topic of discussion in various environments that physical fitness is at a low rate in sedentary societies and at high rates in athletes and it is emphasized that everyone needs to have a good physical fitness [5]. Besides, while the exercise that forms the ground for the physical activities is defined as continuous activities that are planned, constructed, voluntary and aiming to improve one or more factors of physical vitality (cardiovascular fitness, muscle strength and muscular durability, flexibility and body composition), the fitness exercises are described as the application of planned physical activities that are intended for objectives such as vitality, physical performance, weight control and staying healthy [6].

The fitness exercises that are preferred for a healthy life, different from all of the other types of sport activities, have the main purpose of firming and strengthening the muscles via working out with or without tools [7]. This study is valid for all branches of sport because in every sport branch there are muscle groups that are used at a higher rate. The exercises that are performed in order to help these muscle groups gain condition are known to be through fitness exercises [8].

The training programs show differences in accordance with different individuals and different purposes. Thus, it is 
not possible to talk about a standard of training in the fitness sport. In other words, each age group and body shape requires specific schedules and this process must be followed by experts. Being healthy should be prioritized and developed. In addition, cardiovascular training (activities that will leave a person almost breathless, burn calories and establish vitality, such as running and pedaling) should be performed alongside with weight exercises in fitness training. Therefore, the muscles do not grow too much, but rather get firmer and take an aesthetic appearance [8].

Fitness sport will allow the individual to feel psychologically better and more vital. The self-confidence will also be increased with the body taking a better form. It will accelerate the metabolism, increase the energy and regulate sleep while also pushing stress away by presenting psychological recovery. Fitness sport will allow healthier and quicker thinking while also strengthening cardiovascular systems. It is emphasized that for the people who do the fitness sport for a long period of time, the chances to contract cancer and heart attack become less when compared to the chances they indicated before while fitness will also be effective for burning calories and regulating the body's energy system [9].

In the study we have conducted, the purpose was to evaluate the monthly data of the twelve weeks regarding the participants who performed fitness exercises regularly, in order to examine the changes in the anthropometric measurements and body fat percentages. The anthropometric measurements applied in the study are as follows; body mass index measurement, body weight measurement, shoulder peripheral measurement, chest peripheral measurement, biceps peripheral measurement, thigh peripheral measurement and body fat measurement. It was hypothesized that fitness exercises would lead physical changes in individuals who prefer the type of fitness exercises that include walking, running, pedaling and weight exercises as a form of sportive activity.

\section{Material and Method}

Within the scope of the study, the average age of the participants was determined to be $25.75 \pm 0.93$ while the average height was $175.72 \pm 5.4$ and the average weight determined before the exercises was $70.42 \pm 10.6$. Primarily 48 male adult participants participated in the measurements however, 12 of the participants had to quit the exercises later on due to various reasons. The data of the remaining 36 participants were taken into consideration in the measurements. The participants were informed regarding the process and applications prior to the measurements about the theoretical and practical info of the exercise equipment by the professional trainers and afterwards they have signed a voluntary consent form. The study was limited to 12 weeks, 36 male adult participants and a station of exercise including warming up, running, walking, and pedaling and weight exercises with a follow up cooling down and stretching.

\section{Applied Exercise Model}

Exercises that included warm up, cool down, walking, running, pedaling and weight exercises in an average duration of 90 minutes was applied to the participants for 4 days a week during the period of 12 weeks, four days of which covers warm-up and cooling. Each training day the participants are made to do stretching preceding the main part of the exercise.

The main part included 10-minutes walking exercise intensity of which is raised every two minutes, 20-minutes running exercise and 15-minutes pedaling. Between each station, the participants were allowed to drink water in a minute of rest. Following this exercise loading applied to lower extremities, participants were given 10-minutes rest time. In the second stage of the exercise, participants were made to do approximately 30-minutes weight exercise with the weights calculated according to their local maximal strengths. The exercise was finalized with a stretching exercise.

\section{Anthropometric Measurements}

The body weight was measured with a scale with the sensibility of $0.01 \mathrm{~kg}$ and the height was measured with the metal rod of the same scale, which had a sensibility of 0.1 $\mathrm{cm}$ [10]. The participants wore only shorts during all of the measurements. The participants' heads were upright, their knees stretched, heels adjoint and bodies in an upright position during the measurements. The body mass indexes of the participants were calculated via weight/height ${ }^{2}[11]$.

In order to determine the body fat percentages, the subcutaneous fat was calculated with the use of a Holtain brand skinfold caliper that applied $1 \mathrm{~g} / \mathrm{mm}^{2}$ pressure in every angle. The skinfold caliper measurements were performed always from the right side and through seven standard areas (Biceps, Triceps, Pectoralis, Sub-scapula, Abdomens, Supra-iliac and Quadriceps) and every measurement was carried out while the participants were in the proper position. The body fat percentage (\%) was calculated by using the values taken from the measurement points (Lange formula; [(Biceps + Triceps + Pectoralis + Sub-scapula + Suprailic + Quadriceps $) \times(0.097)+3.64])$ [11]. The girth measurements were taken in due form from the calf, arm, waist, chest and shoulder areas with a measuring tape that is not flexible but can bend.

\section{Statistical Evaluation}

The data collected from the participants was transferred over to the SPSS 15.0 software, evaluated through one-way ANOVA tests for mean, standard deviation, and correlated samplings. 


\section{Findings}

Table 1. The Body Mass Index Measurement Values of the Participants

\begin{tabular}{|c|c|c|c|c|}
\hline $\mathrm{N}$ & $\begin{array}{l}\text { Measurement } \\
\text { Time Mean } \pm \text { ss }\end{array}$ & $\begin{array}{c}\text { Measurement } \\
\text { Time Mean } \pm \text { ss }\end{array}$ & $\begin{array}{c}\text { Difference } \\
\text { Between } \\
\text { Means } \\
\end{array}$ & $\mathrm{P}$ \\
\hline \multirow{3}{*}{36} & \multirow{3}{*}{$\begin{array}{c}\text { Pre-exercise } \\
23,07 \pm 3,18\end{array}$} & $\begin{array}{c}\text { 4th Week } \\
23,15 \pm 2,80\end{array}$ & $-0,084$ & 0.913 \\
\hline & & $\begin{array}{c}\text { 8th Week } \\
23,38 \pm 2,64\end{array}$ & $-0,314$ & 0.606 \\
\hline & & $\begin{array}{l}\text { 12th Week } \\
23,68 \pm 2,37\end{array}$ & $-0,603$ & 0.169 \\
\hline
\end{tabular}

No significant difference was found between the BMI means of the participants taken prior to starting the fitness exercises and the measurements taken during the fourth, eighth and twelfth weeks $(p>0,05)$. (Table 1, Fig. 1)

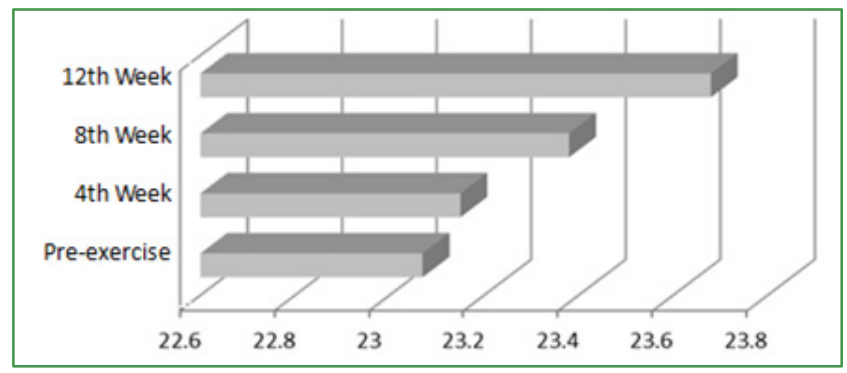

Figure 1. Body MassIndexesGraph of theParticipants

Table 2. The Body Weight Measurement Values of the Participants

\begin{tabular}{|c|c|c|c|c|}
\hline $\mathrm{n}$ & $\begin{array}{c}\text { Measurement } \\
\text { Time } \\
\text { Mean } \pm \mathrm{ss}\end{array}$ & $\begin{array}{c}\text { Measurement } \\
\text { Time Mean } \pm \mathrm{ss}\end{array}$ & $\begin{array}{c}\text { Difference } \\
\text { between means }\end{array}$ & $\mathrm{P}$ \\
\hline \multirow{3}{*}{36} & $\begin{array}{c}\text { 4th Week } \\
71,24 \pm 9.67\end{array}$ & $-0,828$ & 0.099 \\
\cline { 3 - 5 } & $\begin{array}{c}\text { Pre-exercise } \\
70,42 \pm 10,63\end{array}$ & $\begin{array}{c}8 \text { th Week } \\
72,07 \pm 8.94\end{array}$ & $-1,658$ & 0.079 \\
\cline { 3 - 5 } & $\begin{array}{c}12 \text { th Week } \\
73,50 \pm 7.80\end{array}$ & $-3,083$ & 0.008 \\
\hline
\end{tabular}

Upon the inspection of the study's body weight measurement values, no significant difference was found between the values of the 4th and 8th weeks when compared with the values of the pre-exercise $(p>0.05)$. However, the body weight measurements of the 12 th week showed a drastic increase when compared to pre-exercise. $(\mathrm{p}<0.05$ ). (Table 2, Fig. 2)

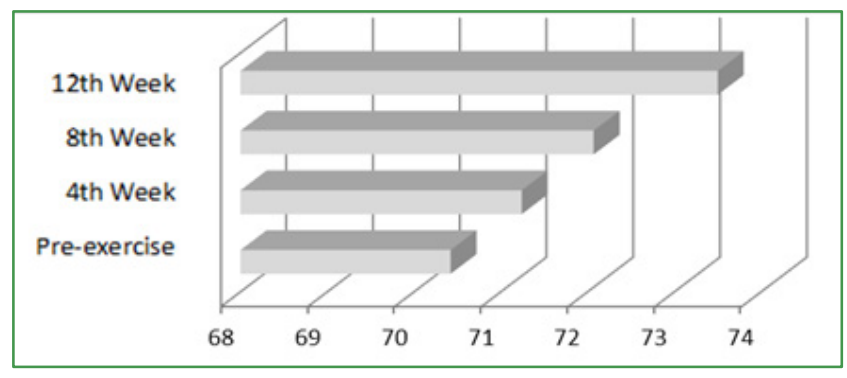

Figure 2. The Body Weight Graph of the Participants
Table 3. The Shoulder Peripheral Measurement Values of the Participants

\begin{tabular}{|c|c|c|c|c|}
\hline $\mathrm{n}$ & $\begin{array}{c}\text { Measurement } \\
\text { Time } \\
\text { Mean } \pm \mathrm{ss}\end{array}$ & $\begin{array}{c}\text { Measurement } \\
\text { Time Mean } \pm \mathrm{ss}\end{array}$ & $\begin{array}{c}\text { Difference } \\
\text { between } \\
\text { means }\end{array}$ & $\mathrm{P}$ \\
\hline \multirow{3}{*}{36} & $\begin{array}{c}\text { 4th Week } \\
112,36 \pm 5,91\end{array}$ & $-1,806$ & 0.000 \\
\cline { 3 - 5 } & Pre-exercise & $\begin{array}{c}8 \text { th Week } \\
114,22 \pm 5,53\end{array}$ & $-3,667$ & 0.000 \\
\cline { 3 - 5 } & $110,56 \pm 6,41$ & $\begin{array}{c}12 \text { th Week } \\
116,50 \pm 5,62\end{array}$ & $-5,944$ & 0.000 \\
\hline
\end{tabular}

A significant difference was identified between all of the measurements in the mean values of the shoulder peripheral measurements of the participants when compared to the measurements of pre-exercise $(p<0.05)$. (Table 3, Fig. 3)

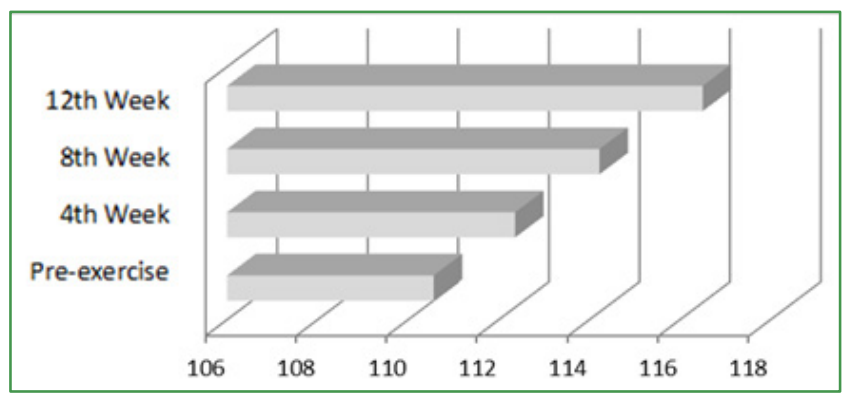

Figure 3. The Shoulder Peripheral Measurement Graph

Table 4. The Chest Peripheral Measurement Values of the Participants

\begin{tabular}{|c|c|c|c|c|}
\hline $\mathrm{n}$ & $\begin{array}{l}\text { Measurement } \\
\text { Time } \\
\text { Mean } \pm \text { ss }\end{array}$ & $\begin{array}{c}\text { Measurement } \\
\text { Time Mean } \pm \text { ss }\end{array}$ & $\begin{array}{c}\text { Difference } \\
\text { between } \\
\text { means }\end{array}$ & $\mathrm{P}$ \\
\hline \multirow{3}{*}{36} & \multirow{3}{*}{$\begin{array}{c}\text { Pre-exercise } \\
90,83 \pm 5,79\end{array}$} & $\begin{array}{c}\text { 4th Week } \\
92,33 \pm 5,81\end{array}$ & $-1,500$ & 0.000 \\
\hline & & $\begin{array}{c}\text { 8th Week } \\
94,01 \pm 5,58\end{array}$ & $-3,181$ & 0.000 \\
\hline & & $\begin{array}{l}\text { 12th Week } \\
96,72 \pm 5,39\end{array}$ & $-5,889$ & 0.000 \\
\hline
\end{tabular}

When the chest peripheral measurements of the participants within the duration of the 12 weeks is examined, it is seen that when compared to the values of pre-exercise, all of the measured values in the 4th, 8th and 12th weeks show a significant difference $(p<0.05)$. (Table 4, Fig. 4)

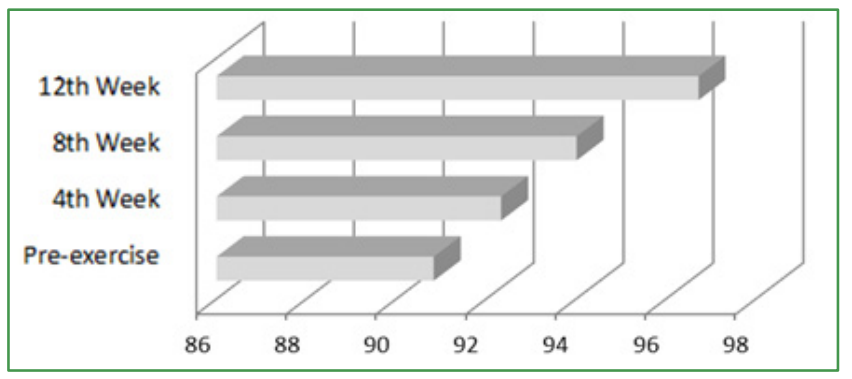

Figure 4. The Chest Peripheral Measurement Graph 
Table 5. The Biceps Peripheral Measurement Values of the Participants

\begin{tabular}{|c|c|c|c|c|}
\hline $\mathrm{n}$ & $\begin{array}{l}\text { Measurement } \\
\text { Time } \\
\text { Mean } \pm \text { ss }\end{array}$ & $\begin{array}{c}\text { Measurement } \\
\text { Time Mean } \pm \text { ss }\end{array}$ & $\begin{array}{c}\text { Difference } \\
\text { between } \\
\text { means }\end{array}$ & $\mathrm{P}$ \\
\hline \multirow{3}{*}{36} & \multirow{3}{*}{$\begin{array}{c}\text { Pre-exercise } 29, \\
89 \pm 1,97\end{array}$} & $\begin{array}{c}\text { 4th Week } \\
30,83 \pm 2,17\end{array}$ &,- 944 & 0.000 \\
\hline & & $\begin{array}{c}\text { 8th Week } \\
32,11 \pm 1,76\end{array}$ & $-2,222$ & 0.000 \\
\hline & & $\begin{array}{l}\text { 12th Week } \\
33,47 \pm 1,86\end{array}$ & $-3,583$ & 0.000 \\
\hline
\end{tabular}

During the 12 week biceps measurements, the 4th, 8th and 12th week measurement values showed a statistically significant increase $(\mathrm{p}<0,05)$ when compared to the values of the pre-exercise. (Table 5, Fig. 5)

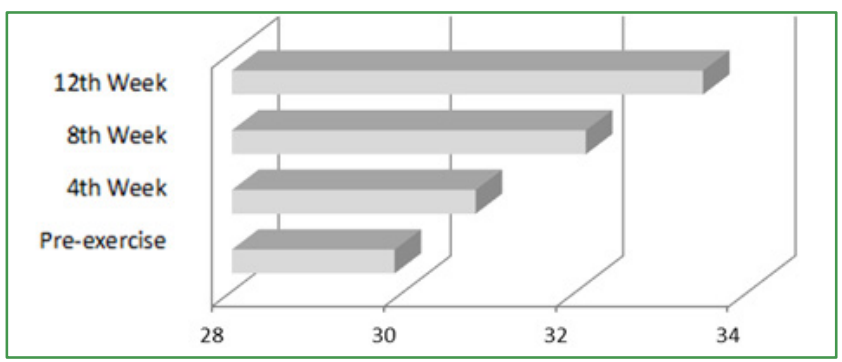

Figure 5. The Biceps Peripheral Measurement Graph

Table 6. The Thigh Peripheral Measurement Values of the Participants

\begin{tabular}{|c|c|c|c|c|}
\hline $\mathrm{n}$ & $\begin{array}{c}\text { Measurement } \\
\text { Time } \\
\text { Mean } \pm \text { ss }\end{array}$ & $\begin{array}{c}\text { Measurement } \\
\text { Time Mean } \pm \text { ss }\end{array}$ & $\begin{array}{c}\text { Difference } \\
\text { between } \\
\text { means }\end{array}$ & $P$ \\
\hline \multirow{3}{*}{36} & \multirow{3}{*}{$\begin{array}{l}\text { Pre-exercise } \\
48,56 \pm 3,53\end{array}$} & $\begin{array}{c}\text { 4th Week } \\
50,29 \pm 3,77\end{array}$ & $-1,736$ & 0.000 \\
\hline & & $\begin{array}{c}\text { 8th Week } \\
52,25 \pm 3,57\end{array}$ & $-3,694$ & 0.000 \\
\hline & & $\begin{array}{l}12 \text { th Week } \\
53,89 \pm 3,28\end{array}$ & $-5,333$ & 0.000 \\
\hline
\end{tabular}

When the thigh peripheral measurements of the participants within the duration of the 12 weeks is examined, it is seen that when compared to the values of pre-exercise, all of the measured values in the 4th, 8th and 12th weeks show a significant difference $(p<0.05)$. (Table 6, Fig. 6)

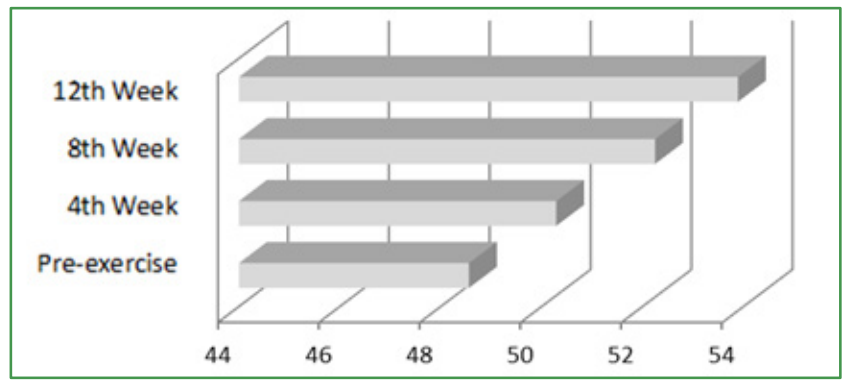

Figure 6. The Thigh Peripheral Measurement Graph
Table 7. Body Fat Percentage Values

\begin{tabular}{|c|c|c|c|c|}
\hline $\mathrm{n}$ & $\begin{array}{c}\text { Measurement } \\
\text { Time } \\
\text { Mean } \pm \mathrm{ss}\end{array}$ & $\begin{array}{c}\text { Measurement } \\
\text { Time Mean } \pm \mathrm{ss}\end{array}$ & $\begin{array}{c}\text { Difference } \\
\text { between } \\
\text { means }\end{array}$ & $\mathrm{P}$ \\
\hline \multirow{3}{*}{36} & $\begin{array}{c}\text { Pre-exercise } \\
15,72 \pm 4,79\end{array}$ & $\begin{array}{c}\text { 8th Week } \\
13,65 \pm 4,87\end{array}$ & 2,069 & 0.000 \\
\cline { 3 - 5 } & & $12,91 \pm 4,64$ & 2,806 & 0.000 \\
\cline { 3 - 5 } & & $\begin{array}{c}12 \text { th Week } \\
11,81 \pm 4,53\end{array}$ & 3,903 & 0.000 \\
\hline
\end{tabular}

According to the Table 7, when the body fat percentages of the participants are examined, a significant difference was found between the 4th, 8th, 12th week measurements and the pre-exercise. $(\mathrm{p}<0,05)$. (Table 7 , Fig. 7)

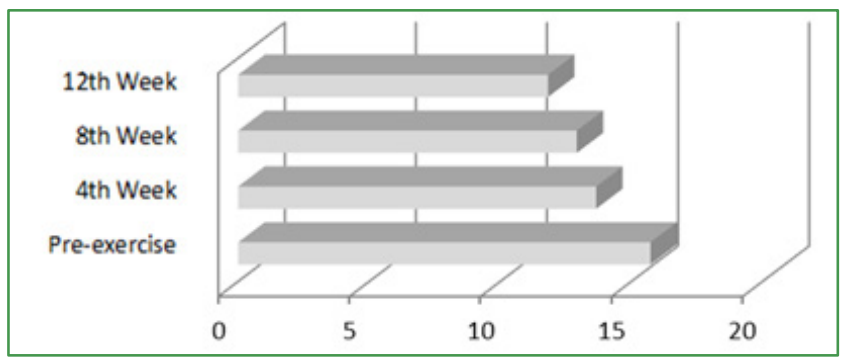

Figure 7. The Body Fat Percentages Graph of the Participants

\section{Discussion}

The purpose of this study was to examine the physical changes in individuals who prefer the type of fitness exercises that include walking, running, pedaling and weight exercises as a form of sportive activity.

Physical fitness is described as being able to perform the daily tasks lively and awake, without feeling tired and having the energy to spend spare time with cheerful activities while also having the sufficiency to deal with unexpected dangers [12].

When the Body Mass Indexes (BMI) of the 36 participants with the average age of $25.75 \pm 0.93$ were examined, the values that were $23.07 \pm 3.18$ prior to the exercises were measured again as $23.15 \pm 2.80$ in the end of the 4 th week, as $23.38 \pm 2.64$ in the end of the 8 th week and as $23.68 \pm 2.37$ in the end of the 12 th week. When the results are examined, it is seen that none of the measurements that were carried out after the exercises reflect statistically significant results when compared to the measurements of pre-exercises. Ünlü (2015) [13] has examined the effects of different strength exercises during 12 weeks and found the BMI values of a group that performed strength exercises similar to our exercise program, as the pre-test results as $21.99 \pm 2.30$, and the post-test results as $22.63 \pm 2.15$. The fact that the researcher reported the findings of the study as having no significant meaning in the end of the twelve weeks supports our findings. Our findings are thought to be related to the body weight and peripheral measurements 
that were measured during the same period of time. However the body weight levels of the participants that were measured as $70.42 \pm 10.63$ prior to the exercises and $73.50 \pm 7.80$ after the twelve week period, showed a significant level of increase. In addition, the Body Fat Percentages of the participants which were tracked for 12 weeks were identified as $15.72 \pm 4.79$ in the first measurement, while cruising at low levels through all of the later measurements and finally being recorded as $11.81 \pm 4.53$ in the twelfth week, thus showing significantly low level results.

Kerry et al. (2005)[14] in their study which included 51 exercises and 53 participants in the control group, have found a significant difference in favor of the BFP of the post-tests while comparing the pre-test and post-test results of the exercise group participants that performed aerobics and durability exercises during a 6 month period. In another study researching the effect of regular exercises on the body fat percentages, Williams et al. (2001:264)[15], have researched the effects of various training groups on physical and physiological performance and as a result of the study, have noted the decrease in body fat percentage of all of the groups as $5 \%-6 \%$. In another study, Nindl et al. (2000) [16] have applied an exercise program that consisted of resistance and aerobic combinations, lasted for a total of 6 months while being carried out 5 days a week, and reported that they have found a $10 \%$ decrease in the fat weight. The findings of the researchers show similarities with our results.

As another parameter, peripheral measurements measured for the participants are found to be supporting the BMI values. These BMI values did not significantly differentiate from the body weight values that increased in spite of the decreasing body fat percentages at the end of this 12-week period. However, upon the examination of the peripheral measurement values of the participants, the peripheral measurement values that were measured as $110.56 \pm 6.41$ prior to the exercises have reflected a significant increase in the 4th, 8th and 12th weeks and measured as $116.50 \pm 5.62$ in the end of the twelfth week. Similarly, the chest peripheral measurements that were measured prior to the exercises showed a mean of $90.83 \pm 5.79$ and a significant increase in the measurements of the following weeks, resulting as $96.72 \pm 5.39$. The biceps peripheral measurements of the participants prior to the exercises showed a mean of $29.89 \pm 1.97$ and the measurements after the 12 th week resulted as $33.47 \pm 1.86$. This increase is observed to be statistically significant. In another measurement, the thigh peripherals of the participants showed an average of $48.56 \pm 3.53$ prior to the exercises and $53.89 \pm 3.28$ upon the end of the 12 week period. The difference was found to be statistically significant.

The body weight and peripheral measurements of the participants showed an increase without a significant increase in the BMI values. This result was interpreted as a natural reflection of the participants performing the majority of the fitness exercises as weight exercises that were aimed at improving the muscle mass throughout the twelve week period on the muscle volume. This interpretation in this study is supported by researchers.

Bottaro et al., 2009[17]; Wakaharu et al., 2012) [18] state that regular strength training improves the muscle strength along with muscle hypertrophy. In addition, the fact that Staron et al., (1991) [19] came to the conclusion that heavy resistance exercises results in increased muscle strength while being an effective mechanism stimulating the muscle hypertrophy, is an important sign of support regarding the peripheral measurements that were determined as a result of our study. On the other hand, it has been stated that the strength training can show differences depending on the physical features and overweight individuals perform strength trainings in order to lose weight quicker by accelerating their metabolisms. Researchers (Bompa, 1999[20]; Watts et al., 2005) [21] state that individuals of medium-level weight perform strength trainings in order to increase the amount of muscle mass and that the strength trainings boost both the basal metabolism and muscle mass. The reports of the researchers support our results regarding our participants that form the workgroup of our study, have medium-level body weight and perform fitness exercises with the aim of increasing the muscle mass.

\section{Results}

The results of our study indicate that regular fitness exercises contributes to the increase in the body mass index while decreasing the body fat percentages as well as having an important effect on gaining a physical appearance that is fit and spry.

\section{Suggestions}

In our contemporary era, the fact that a life without movement can cause many illnesses such as obesity and cardiovascular illnesses is scientifically proven. Similarly, in the light of the results of this study, it can be suggested that every individual should view exercising regularly and in a planned manner as an important part of his/her own life.

For further researches, conducting these studies on women and with various age groups can provide fruitful results and applications, and it will be beneficial for the field.

\section{REFERENCES}

[1] Cox L, Burke V MA. Long-Term Effects of Exercise on Blood Pressure and Lipids in Healthy Woman Aged 40-65 Years: The Sedentary Women Exercise Adherence Trial 
(Sweat). Journal of Hypertension. 2001;19.

[2] Rogerio A, Lobo M. 1994.Treatment of thePostmenopausalWomen, Basic andClinicalAspects. 1994;8.

[3] Shangold M. Exercise in the Menopausal Wome. ObstetGynecol. 1990;4.

[4] Herguner G, Bar M, Yaman M. Beden eğitimi ve spor etkinliklerine katılan ortaokul öğrencilerinin aile, okul yöneticileri ve öğretmenlerden beklentilerinin belirlenmesi. International Journal of Human Sciences. 2016;1:13.

[5] Zorba E. Yaşam Boyu Spor. Morpa yanınevi. 2004;1:53.

[6] Thompson W, Gordon N, Pescatello L, ACSM's. Guidelines for ExerciseTesting and Prescription. 8th ed Baltimore, MD: Lippincott Williams\&Wilkins. 2009;8.

[7] Frank J. Coordination of Postureand Movement. PhysTher. $1990 ; 12$.

[8] Karagöz T. 30-40 Yaş Arası Bayanların Fitness Sporuna Katılım Nedenleri ve Beklentileri. 2008:72.

[9] Zorba E. Fiziksel Uygunluk. Gazi Kitabevi, Ankara. 2001;2:64.

[10] Tamer K. Sporda fiziksel-fizyolojik performansın ölçülmesi ve değerlendirilmesi. Ankara: Bağırgan Yayımevi. 2000;2.

[11] Özer K. Antropometri - Sporda morfolojik planlama. İstanbul: Kazancı Matbaacıl1k. 1993.

[12] Özer M. Fiziksel Uygunluk. 1 Baskı, Nobel Yayın Dağıtım. 2001.

[13] Ünlü G. Farklı Kuvvet Antrenmanlarının Kas Kuvveti ve
Hipertrofisi Üzerine Etkileri. Akdeniz Üniversitesi Sağlık Bilimleri Enstitüsü. 2015:28.

[14] Kerry S, Anita B, Katherine T, Jeremo F, Paul H, Edward S. Effect of exercise on blood pressure in older persons. ArchIntern Med. 2005;6.

[15] William J, Monica K, Nicholas A, Jeff S, Mathew M, Jill A, et al. Resistance Training Combined With Bench-Step Aerobics Enhances Woman's Health Profile. Medicine Science in Sports Exercise. 2001;2.

[16] Nindl B, Harman E, Marx J, Gotshalk L. Regional Body Composition Changes in Women After 6 Months of Periodized Physical Training. Journal of Applied Physiology. 2000;6.

[17] Bottaro M, B. M, Gentil P, Wagner D. Effects of rest duration between sets of resistance training on acute hormonal responses in trained women. Journal of Science and Medicine in Sport. 2009;12.

[18] Wakaharu T, Miyamoto N, Norihide S, Murata K, Kanehisa $\mathrm{H}$, Kawakami Y. Association between regional differences in muscle activation in ones ession of resistance exercise and in muscle hypertrophy after resistance training. European Journal of Applied Physiology. 2012;112.

[19] Staron R, Karapondo D, Kraemer W, Fry A, Gordon S, Falkel $\mathrm{J}$, et al. Skeletal muscle adaptations during early phase of heavy resistance trained in man and women. J Appl Physiol. 1994;3.

[20] Bompa T. Theory and Methodology of Training. Human Kinetics. 1999.

[21] Watts K, Jones T, Davis E, Green D. Exercise training in obese children and adolescents: current concepts. Sports Medicine 2005. 